\title{
Usefulness of Imprint Cytology in Cancer Cervix
}

\author{
Abha Singh $^{1}$, Ruchi Kishore ${ }^{2}$, Jayanti Chandrakar
}

\begin{abstract}
Introduction: Tissue diagnosis in cancer cervix is much prior to its definitive management. Though histopathologic examination is accurate but it consumes time. Imprint cytology is a simple, quick and inexpensive diagnostic modality which can reduce the waiting period for management effectively.

Objective: The aim of this study was to compare the diagnostic accuracy of imprint cytology with histopathology in cancer cervix.

Materials and methods: The study included 150 women with clinical diagnosis of cancer cervix. All women underwent punch biopsy from the cervical growth. Imprint cytology slides were prepared and tissue was then sent for histopathology examination.

Result: The diagnostic accuracy of imprint cytology was $92 \%$ as compared to $98 \%$ for histopathology. The time taken for interpretation for imprint cytology was 1.5-2.5 hours while for histopathology, it was 7-10 days.

Conclusion: Imprint cytology is a simple, rapid and inexpensive diagnostic modality with very good accuracy. It can effectively reduce the time in tissue diagnosis in cancer cervix.

Keywords: Cancer, Cervix, Cytology, Imprint.

Journal of South Asian Federation of Obstetrics and Gynaecology (2019): 10.5005/jp-journals-10006-1703
\end{abstract}

\section{InTRODUCTION}

Indian women bear the greatest brunt of cancer cervix accounting for more than a quarter of new cases and cervical cancer deaths worldwide. Out of the 530,000 cases 134,000 were reported in India. Awfully 73,000 women die due to cancer cervix in India alone.,

The definitive management of cancer cervix is aggressive either in the form of radical hysterectomy or radiotherapy therefore needs confirmatory tissue diagnosis prior to it. Though histopathological examination is definitive but is costly, requires expert technical staff and consumes around 4-7 days. Advanced stage of cancer cervix sometimes requires repeat analysis due to necrosis. This further lingers the management.

Imprint cytology is a simple and rapid technique for tissue diagnosis. Imprint smear is prepared after touching the tissue on the glass slide to leave its imprint in the form of cells, which is studied after proper staining. Its cost effectiveness and its ability to maximize cell recovery from very small tissue piece makes touch imprint cytology a valuable resource for virtually every aspect of experimental and diagnostic medicine. ${ }^{3}$ In present scenario where cost and time containment has become a critical factor we tried to investigate the diagnostic accuracy and usefulness of touch imprint cytology in cancer cervix. Solely no study till now has been conducted on relevance of imprint cytology in cancer cervix, so the present study was undertaken.

\section{Aims and Objective}

To compare the diagnostic accuracy of imprint cytology with histopathology in cancer cervix.

\section{Materials and Methods}

This prospective study was conducted in Pt. JN Medical College and Dr BR Ambedkar Hospital Raipur, Chhattisgarh, between February 2015 and July 2015. All women with clinical diagnosis of cancer cervix
${ }^{1}$ Pt. Jawahar Lal Nehru Memorial Medical College, Raipur, Chhattisgarh, India

${ }^{2}$ Department of Obstetrics and Gynecology, Pt. Jawahar Lal Nehru Memorial Medical College, Raipur, Chhattisgarh, India

${ }^{3}$ Department of Pathology, Pt. Jawahar Lal Nehru Memorial Medical College, Raipur, Chhattisgarh, India

Corresponding Author: Ruchi Kishore, Department of Obstetrics and Gynecology, Pt. Jawahar Lal Nehru Memorial Medical College, Raipur, Chhattisgarh, India, Phone: +91 7024804784, e-mail: ashishkumarruchi@yahoo.com

How to cite this article: Singh A, Kishore R, Chandrakar J. Usefulness of Imprint Cytology in Cancer Cervix. J South Asian Feder Obst Gynae 2019;11(4):249-251.

Source of support: Nil

Conflict of interest: None

were included in the study. Punch biopsy was taken from the cervical growth. Slides were properly labeled by glass marking pencil. Biopsy sample was kept on a dry gauge to remove blood. The biopsy sample was then gently touched to the slide at 3-4 places avoiding gliding movement. The slide was immediately dipped for one minute into a $95 \%$ ether-alcohol solution. The tissue was then fixed in formalin and embedded in paraffin for conventional histopathology diagnosis. The slides were then stained in hematoxylin for one minute followed by rapid rinsing in distilled water, differentiation with ammonium hydroxide, counter staining with eosin, quick dehydration in absolute alcohol and cleansing in xylol. The specimen was then mounted in Canada balsam, and a cover slip was affixed. The entire process took less than five minutes. The permanent paraffin sections were used to make the definitive or "proven" diagnosis.

Concordance of histocytology for malignant tumors was assessed by using a point system:

(-) The Author(s). 2019 Open Access This article is distributed under the terms of the Creative Commons Attribution 4.0International License (https://creativecommons. org/licenses/by-nc/4.0/), which permits unrestricted use, distribution, and non-commercial reproduction in any medium, provided you give appropriate credit to the original author(s) and the source, provide a link to the Creative Commons license, and indicate if changes were made. The Creative Commons Public Domain Dedication waiver (http://creativecommons.org/publicdomain/zero/1.0/) applies to the data made available in this article, unless otherwise stated. 
- 0 point-slides of nondiagnostic quality.

- 1 point-slides show either benign or atypical cells.

- 2-point-slides with malignant cells present but in which a specific cell type cannot be recognized.

- 3-point-slides revealing the specific malignant histological cell type.

\section{Results}

In the present study, the prevalence of stage I cancer cervix was only $4 \%$ and maximum (60\%) of cases belonged to stage II (Table 1). The conventional biopsy reports were inadequate in $2 \%$ of women. $25 \%$ of total biopsy specimens were insufficient in stage IV. The results were erroneous due to lesser number of cases in this stage (Table 2). Inadequate biopsy samples were repeated. One hundred percent of histopathology was then concordant with clinical diagnosis. Four percent of the total imprint smears were of nondiagnostic value, another $4 \%$ were negative for malignancy. Malignant cells were seen in total $92 \%$ of slides, out of which $86 \%$ could diagnose the type of malignancy too (Table 3 and Figure 1). The diagnostic accuracy of imprint cytology was $92 \%$ (Table 4). Only $1.33 \%$ of total cancer cervix were adenocarcinoma. All of which could be diagnosed by imprint cytology. The results of imprint cytology could be obtained in 1.5-2.5 hours and the cost of imprint cytology was less than half of histopathology (Table 5).

\section{Discussion}

According to the WHO (2008) maternal deaths and cervical cancer cases are almost equal in India. ${ }^{4}$ A study from Chennai, India, states

Table 1: Distribution of cancer cervix cases according to clinical staging

\begin{tabular}{lcc}
\hline Clinical staging & No. of cases & $\%$ \\
\hline I & 6 & 4 \\
II & 90 & 60 \\
III & 36 & 24 \\
IV & 4 & 2.67 \\
Recurrence & 14 & 9.33 \\
Total & 150 & 100 \\
\hline
\end{tabular}

that only $7 \%$ of women with cancer cervix are diagnosed at an early stage. ${ }^{5}$ The reality is still bitter in the present study where only $4 \%$ of cancer cervix were from stage I. Maximum number of cases belonged to stage IIB.

Sampling of tissue has its own limitations. Even in the best hands inadequacy may result. In the present study 3 out of 150 biopsies were insufficient to infer diagnosis. Tissue taken from the big necrotic growths was not sufficient to diagnose malignancy. Four percent of the slides of imprint cytology were negative for cell because of necrosis and hemorrhage and thus were inadequate for making diagnosis. Similar results were seen in the study from Gujarat which was conducted on tumors of different sites. ${ }^{6}$ One hundred and twenty-nine out of 150 slides could diagnose the type of malignancy while in $6 \%$ of slides malignancy was diagnosed but the type could not be established. Harnish et al. also reported the ability of tissue imprint cytology to identify malignancy with specific sub types in $86.31 \%{ }^{6}$

The overall accuracy for the diagnosis of malignancy in present study was $92 \%$ which is in accordance to studies by Mehar et al. and Harnish et al. where accuracy was $90 \%$ and $92.63 \%$, respectively. ${ }^{6,7}$ The cellular details are more clear in imprint cytology as compared to histopathology while the architectural details are better in histopathology (Fig. 1).

Though histopathology appearance of a lesion in any organ is considered final arbiter of its diagnosis, yet the delay involved may affect the course of its treatment. The waiting period for histopathology result was 7-10 days in the present study. Till then the women from remote areas had either to return back to their native place or had to stay back. This imposed the financial and psychological burden on the whole of the family. The definitive management further demanded time and money. Imprint cytology is an answer in these situations. It is cheaper and quicker adjunct to histopathology which provided results in 1.5-2.5 hours as also supported by the study by Fotou et al. which concluded that imprint cytology provides a rapid, preliminary diagnosis in a few minutes. ${ }^{8}$

\section{CONCLUSION}

Imprint smear is simple, rapid and inexpensive diagnostic modality with very good accuracy. It can be used as an adjunct

Table 2: Adequacy of histopathology samples according to clinical stages

\begin{tabular}{|c|c|c|c|c|c|}
\hline Stages & Total & Adequate & $\%$ & Inadequate & $\%$ \\
\hline $\mathrm{I}$ & 6 & 6 & 100 & 0 & - \\
\hline II & 90 & 90 & 100 & 0 & - \\
\hline III & 36 & 34 & 94.45 & 2 & 5.55 \\
\hline IV & 4 & 3 & 75 & 1 & 25 \\
\hline Recurrence & 14 & 14 & 100 & 0 & - \\
\hline Total & 150 & 147 & 98 & 3 & 2 \\
\hline
\end{tabular}

Table 3: Scoring of result of imprint cytology

\begin{tabular}{llllccccc}
\hline & \multicolumn{7}{c}{ Number of cases according to scoring } \\
\cline { 2 - 8 } Clinical staging & 0 & $\%$ & 1 & $\%$ & 2 & $\%$ & 3 \\
\hline I & 1 & 16.66 & 0 & - & 0 & - & 5 \\
II & 2 & 2.22 & 3 & 3.33 & 7 & 7.7 & 78 \\
III & 2 & 5.56 & 2 & 5.56 & 1 & 2.77 & 31 & 86.66 \\
IV & 1 & 25 & 0 & - & 0 & - & 76 \\
Recurrence & 0 & 0 & 1 & 7.15 & 1 & 7.15 & 12 & 85.70 \\
\hline
\end{tabular}



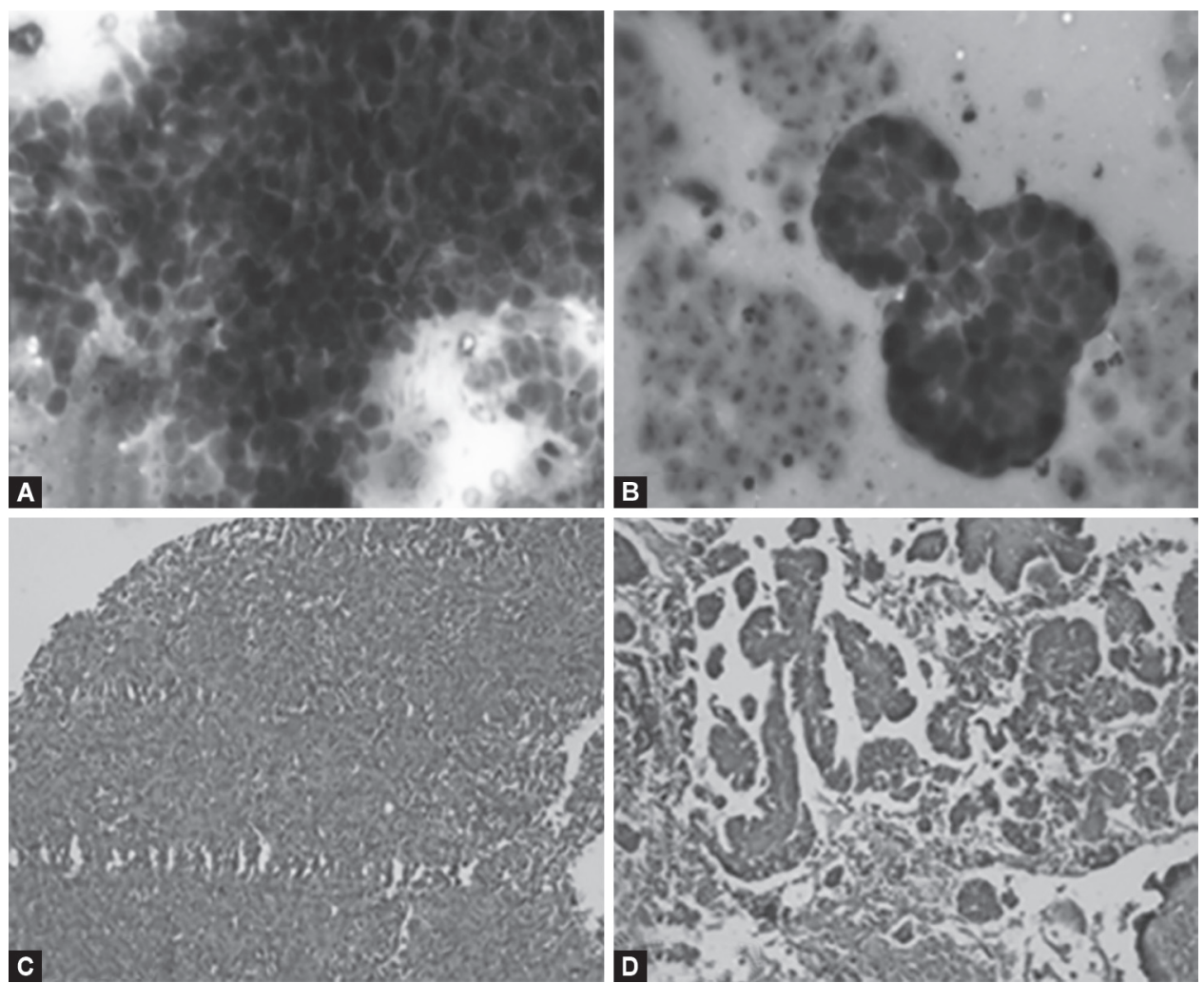

Figs 1 A to D: (A) Imprint cytology on cancer cervix (40× H\&E); (B) Imprint cytology on papillary adenocarcinoma of cervix (40× H\&E); (C) Histology on squamous cell carcinoma of ca cervix $(10 \times \mathrm{H} \& \mathrm{E})$; (D) Histology on papillary adenocarcinoma of ca cervix (10× H\&E)

Table 4: Comparison of diagnostic accuracy of imprint cytology and histopathology according to clinical staging of cancer cervix

\begin{tabular}{lcll}
\hline Clinical staging & $\begin{array}{l}\text { Total number } \\
\text { of cases }\end{array}$ & $\begin{array}{l}\text { Imprint } \\
\text { cytology } \%\end{array}$ & $\begin{array}{l}\text { Histopathology } \\
\%\end{array}$ \\
\hline I & 6 & 83.3 & 100 \\
II & 90 & 94.4 & 100 \\
III & 36 & 88.88 & 94.44 \\
IV & 4 & 75 & 75 \\
Recurrence & 14 & 85.7 & 100 \\
Overall & 150 & 92 & 98 \\
accuracy & & & \\
\hline
\end{tabular}

Table 5: Comparison between salient features of imprint cytology and histopathology

\begin{tabular}{lll}
\hline & Imprint cytology & Histopathology \\
\hline Diagnostic accuracy & $92 \%$ & $98 \%$ \\
Time taken & $1.5-2.5$ hours & $7-10$ days \\
Trained technical staff & Not required & Mandatory \\
Approximate cost & 300 Rs & 700 Rs \\
\hline
\end{tabular}

to histopathology with minimal cost inflation. It is useful in under resourced settings where trained technical staffs are not available. The waiting period for the tissue diagnosis can be effectively reduced from nearly a week to few hours thus saving the time and money. An early decision can be made about management in an already advanced devastating disease.

\section{References}

1. Ferlay J, Shin H-R, Bray F, et al. Estimates of worldwide burden of cancer in 2008: GLOBOCAN 2008. Int J Cancer J Int Cancer 2010;127(12):2893-2917. DOI: 10.1002/ijc.25516.

2. Arbyn $M$, Castellsagué $X$, de Sanjosé $S$, Bruni L, Saraiya M, Bray $F$, et al. Worldwide burden of cervical cancer in 2008. Ann Oncol Off J Eur Soc Med Oncol ESMO 2011;22(12):2675-2686. DOI: 10.1093/ annonc/mdr015.

3. Mangia A, Chiriatti A, Chiarappa P, et al. Touch Imprint Cytology in Tumor Tissue Banks for the Confirmation of Neoplastic Cellularity and for DNA Extraction [Internet]. http://www.iss.it/binary/ribo/cont/ Mangia\%20et\%20al.2008.1233761170.pdf. 2008 [cited 2015 Aug 11]. Available from: http://www.iss.it/binary/ribo/cont/Mangia\%20et $\% 20$ al.2008.1233761170.pdf.

4. WHO|Recommendation 2: Health indicators [Internet]. WHO. [cited 2015 Aug 11]. Available from: http://www.who.int/woman_child_ accountability/progress_information/recommendation2/en/.

5. Gakidou E, Nordhagen S, Obermeyer Z. Coverage of Cervical Cancer Screening in 57 Countries: Low Average Levels and Large Inequalities. PLoS Med 2008;5(6):e132. DOI: 10.1371/journal.pmed.0050132.

6. Harnish B, Nidhi V, Neena D. Usefulness of touch imprint cytology in cancer diagnosis: A study of 119 cases. Int Res J Med Sci 2014;2(10):25.

7. Mehar R, Panchonia A, Kulkarni CV. Study of imprint smears of various lesions with histological correlation. International Journal of Medical Science and Public Health 2014;3(4):486-488. http://www.scopemed. org. 2014 [cited 2015 Aug 11]. Available from: http://www.scopemed. org/?mno=152221.

8. Fotou M, Oikonomou V, Zagouri F, et al. Imprint cytology on microcalcifications excised by vacuum-assisted breast biopsy: a rapid preliminary diagnosis. World J Surg Oncol 2007;5:40. DOI: 10.1186/1477-7819-5-40 